\title{
The military and the fragile democracy of the Philippines
}

\author{
Abstract for chapter 4
}

\section{Author: Viberto Selochan}

The Philippines became the first independent democratic country in Asia, adopting a political system modelled on that of the United States. With strong leadership and a weak central state as the hallmarks of Philippine politics, the author questions whether democracy will continue to flourish in the post-Cold War era.

The author outlines the origins of democracy in the Philippines, stating that the American-style democracy exported to the Philippines was bound to encounter problems. When Magaysay became president in 1953, he decided to use the military in government. Marcos, who instituted martial law in 1972, perpetuated this abrogation of democracy. It was only by the end of her term of office in 1992 that Aquino was able to claim that she had restored democracy to the Philippines.

Keywords

democracy, martial law, military 


\section{4}

\section{THE MILITARY AND THE FRAGILE DEMOCRACY \\ OF THE PHILIPPINES}

\section{Viberto Selochan}

On 4 July 1946 the US granted independence to the Philippines, in keeping with its promise of self-determination for the islands after a period of Commonwealth administration. The Philippines thus became the first independent democratic country in Asia. During its colonial administration the US had encouraged the development of political parties, though the two major parties which developed differed little in ideology - the main differences concerning their attitudes to US administration of the islands.

At independence the Philippines political system was modelled on that of the United States, where the constitution required the armed forces to uphold civilian supremacy. As in the US, elections were held every four years in the Philippines, and presidents were limited to two terms in office. This constitutional requirement was initially upheld and the military played a minor role in politics, except to guard polling stations against fraud during elections. Threats by the communist-inspired Hukbalahap movement soon after independence to seize political power and disrupt national elections required the military to play a more active role in monitoring elections. As a result of its success in curbing the insurgents' threat to the country, the military was co-opted into playing a larger role in the administration of former defence secretary, Ramon Magsaysay.

When he was elected president of the republic in 1965, Ferdinand Marcos believed that in a developing country where the military was not occupied with external threats, it should assist in developing the country. He used the military in civic action programs and to enhance his chances of being re-elected. Marcos was the first Philippines president to be elected to a second term in office. Constitutionally deprived of seeking a third term, Marcos declared martial law in 1972 and facilitated the military's playing a larger role in government. When he was forced to leave office in 1986, elements in the military found difficulty in adjusting to the requirements of the democratic system restored by Corazon 
Aquino. To assist in this process, military personnel were subjected to instruction in democratic principles and the role of the military in a democracy. Yet Aquino had to endure seven attempts by the military to seize political power. The survival of her government was due to some extent to the belief among elements of the Armed Forces of the Philippines (AFP) that the military must remain subservient to civilians in a democracy. The military's adherence to democracy was again tested during the national elections in May 1992. There were fears that it would attempt to seize power if the elections were seen to be fraudulent, but with free and fair elections the military adhered to the restored democracy.

Strong leadership and a weak central state have been the hallmarks of Philippine politics. Whether democracy will continue to flourish in the post-Cold-War era, when authoritarian rule is generally in retreat, remains to be seen.

\section{Origins of Democracy in the Philippines}

When the United States colonised the Philippines in 1898 it planned to gradually grant self-determination to the country as the principles of democracy were imbibed by the population. As education was not widespread, the elite and the educated benefitted most from the system instituted by the US, which was largely executed by officers of the US army. Filipinos worked in the American administration and quickly came to value the concept of self-government. By 1917, when the US decided to institute its policy of 'Filipinisation', the elite was ready to assume positions vacated by departing US military officers. Between 1917 and 1935, when the Commonwealth came into existence, political parties were formed and most of the population was educated into accepting the principles of democracy, which meant having a ruling party and an opposition. In this respect, the Philippines was significantly different from many Asian countries which gained independence a few years later. As Apter (1962:154) points out: these countries did not generally accept an opposition as a normal feature of a democracy. The small elite who controlled the political process realised that each party would have its turn in government. The Nacionalista and Liberal parties, which differed little ideologically, dominated politics, and politicians switched parties to gain office. But the democratic system that developed did not represent the majority of the population.

The Philippine Commonwealth was inaugurated in 1935 under a democratic constitution patterned after the United States bicameral system. 'The ideology of American 'democracy' which emphasised the limitation of state power was very different from the philosophy of the French in Indo-China, the Dutch in the Indies and the British in Malaya. It played into the hands of the elite to whom 
the Americans, always ambivalent colonial rulers, proceeded to hand over political power as soon as possible' (Overholt 1986:1136).

For most Filipinos, American-style democracy meant little more than elections every few years. Beyond this, the colonial authorities made sure that only the candidates who represented colonial interests first and last won. This practice did not die with colonialism. The ensuing political order, which persisted long after independence, was one where a handful of families effectively and ruthlessly ruled a society riven by inequality. It was democratic in form, borrowing as many American practices as it could, but autocratic in practice (World Bank report cited in Chomsky 1991:237).

The first duty of the Commonwealth government was national security. President Manuel Quezon procured the services of General Douglas MacArthur, who was about to retire as US Army Chief of Staff, to establish the Philippine military. MacArthur and his US military advisory team used the Swiss army as a model for the Philippine army. A military academy, patterned after the US military academy at West Point, was designed in which officers were to be instructed in the techniques and skills of the military and taught that the proper role of the military in a democracy was one of subservience to civilian government. In practice, however, these ideals were not easily imparted to the new recruits, many of whom attained their place at the academy through political patronage rather than merit (Selochan 1990:57). Courses at the academy were oriented towards equipping cadets to maintain internal law and order through combat techniques. The curriculum did not address subjects in the humanities. Maintaining law and order, more a policing than military function, required more emphasis on domestic politics than military skills. Officers recruited from the Reserve Officers Training Course (ROTC) conducted at the universities were more amenable to humanitarian considerations, but they did not generally hold command positions in the military as they were seen as part-time soldiers. Yet with a liberal education they were possibly more attuned to the democratic process than the officers trained at the Philippines Military Academy (PMA) under an authoritarian military system.

Officers' adherence to democratic practices also suffered under the Commission on Appointments (CA), instituted to vet appointments under a functioning democracy. Politicians who were members of the CA sought and gained allegiance from officers in exchange for approving their promotion. Many officers consequently remained indebted to politicians and were unable to conform strictly to the military chain of command. While the Philippine military was still being developed World War II abruptly interrupted the military training and education program. To defend the islands, the fledgling Philippine military was incorporated 
into the United States Armed Forces for the Far East (USAFFE) under the command of General MacArthur.

At the termination of the war, the Philippines had suffered severe damage. It also had over one million people claiming to be guerilla fighters and thus seeking a place in the military. Reconstruction of the Philippine economy and the reconstitution of the military became priorities of the newly-installed government under President Osmeña. Independence was also granted during this period. But the country was inadequately equipped to assume full sovereignty.

The 1935 constitution, which was adopted at independence on 4 July 1946, provided the framework within which a democratic state could develop.

The Constitution was supplemented by laws enacted by legislatures at the national, provincial, and city/municipal levels of government. A centralised court system which was headed by the Supreme Court performed the judicial function of the state and a career national bureaucracy administered the policies of the government. In other words, the political and institutional infrastructure of a democratic government was in place in the Philippines at the time of independence. What was not altered was the distribution of wealth, economic power and social status (Lapitan 1989:236).

The American-style democracy exported to the Philippines was bound to encounter problems: 'Except in rare instances, democracy does not work when foreign models are imposed, and many features of American democracy are illsuited to poor, unstable and divided countries' (Diamond 1992:27).

\section{The President, the Military and Democracy}

Soon after independence, Philippine democracy was threatened by the communist-inspired Hukbalahap movement. The insurgents who had fought against the occupying Japanese forces resumed their fight against the newly-installed administration; they had little confidence in the Philippine democratic process which they saw as favoring the ruling elite. Appointed Defense secretary, Ramon Magsaysay was, however, determined to restore faith in democracy, and especially the electoral system. Historically, elections in the Philippines were characterised by vote-buying, vote-rigging and the use of private armies to intimidate voters. Magsaysay used the AFP extensively to ensure that the 1951 elections were conducted fairly, and indeed they were alleged to have been the fairest in Philippine electoral history. Although he did not completely restore the Huks' faith in democracy, Magsaysay reformed the military with assistance from the US and defeated the Huks.

Having worked closely with the military, Magsaysay realised that the skills of the officers could be harnessed to develop the country. When he became presi- 
dent in 1953 Magsaysay decided to use the military in government. He appointed active duty officers to perform a range of functions in his administration. By 1954 Congressman Bengson claimed that over 122 active duty officers were performing duties formally the prerogative of civilians (Selochan 1990:118). Justifying this action, the president said that he was weary of the civilian bureaucracy as a whole. Furthermore,

I have needed men of my absolute confidence to undertake delicate missions of investigation and cleaning up... In other cases, specialised skills and technical knowhow were required for quick and official results ... In still other instances, the new administration came upon officers so deeply entrenched in dishonesty and corruption that only the most ruthless, uncompromising kind of military discipline could redeem them from the mire and restore them to gainful usefulness to our people (Magsaysay, quoted in Abueva 1971:315).

Magsaysay, who probably would have been re-elected in the presidential elections of 1957, died in a plane crash that year. Knowing Magsaysay's attitude to the vice-president, Carlos Garcia, many officers who had been closely associated with Magsaysay were reluctant to allow Garcia to assume the presidency. Abortive plans to seize power before the inauguration were hastily and poorly designed (Selochan 1990:122-23), and Garcia assumed the presidency, aware of the military's attitude to him and to the democratic process. For these and other political reasons, Garcia was determined to rid the administration of officers appointed to government by his predecessor. By this stage AFP officers were pervasive in the government. They were in the cabinet positions normally occupied by civilians. After acrimonious debate, Garcia was able to persuade some officers to return to the AFP; others retired their commissions and ran unsuccessfully for office in the 1961 congressional elections.

Many of the officers who had been in Magsaysay's administration believed that they were more capable of governing than civilians. Some officers also believed that these civilians had achieved their positions as a result of political patronage rather than merit. That civilian politicians were corrupt was evident from their activities during elections and from the manner in which they used their positions to acquire favours from businessmen and the AFP. Democracy in the Philippines, according to many of these officers, benefitted the elite who controlled the political process. The majority of Filipinos, they argued, did not understand the concept of democracy; for them it meant being paid to vote for a candidate at elections. Many officers believed that Philippine-style democracy could not contribute to the economic development of the country but was being abused for the benefit of the elite. Authoritarian rule provided the means of 
addressing the situation. But the military was neither united in this view nor capable of seizing political power.

\section{Abrogating Democracy}

A civilian politician, Ferdinand Marcos, was elected president in 1965. Marcos, who claimed a distinguished career as a guerilla fighter during World War II (later disproved), courted the AFP while he was a congressman, but was generally believed to be suspicious of the AFP, which was rumoured to be planning to seize power in 1965 . These rumours were taken seriously by many including the Garcia administration, as there was a series of successful coups in Asia during this period. Concerned about the military's political ambition and believing that a closer relationship with senior officers would serve his long-term interests, Marcos retained the Defense portfolio for the first thirteen months of his administration. During this period he reshuffled the officer corps, promoting officers favourable to his political agenda and retiring others less amenable. The military was subsequently enlisted to assist in his re-election campaign. Marcos became the first Philippine president to be re-elected in what became one of the most violent and fraudulent elections in the country's history. Increasingly during his second term he became dependent on the AFP to remain in office. To serve the interests of the president, the military harassed the opposition and violently quelled demonstrations against the government.

Constitutionally prevented from remaining in office for a third term, Marcos declared martial law in 1972, with the consent of the military, under the pretext of saving the country from Communist and Muslim insurgencies. Martial law allowed the AFP to play a larger role in government. Because democracy was so easily abrogated it has been argued that it had not in fact taken root in the Philippines. But then, 'A democratic constitution does not make a democracy; only democratic, constitutional behaviour that follows a long period of experience and education can truly constitute democracy' (Gastil 1985:161). Although the 1935 constitution had enshrined democratic principles and structures of government, political practice differed considerably from the theory (Reyes 1988:268).

Marcos argued that the democratic system would not allow him to develop the 'New Society' he envisaged for the Philippines. For him, the practice of democracy was 'energy-consuming' and 'time-wasting'; authoritarian rule allowed him to make the changes he wanted without having to endure democratic procedures (Hernandez 1985:243). Under his self-styled constitutional-authoritarianism the institutions of democracy were dismantled: Congress was disbanded, political parties were declared illegal, and civil and political rights were sus- 
pended. Freedom, a fundamental tenet of democracy, was taken away from Filipinos. As commander-in-chief, Marcos directed the AFP to carry out martial law functions. The military was, according to the principles of democracy, to remain subservient to the civilian head of state. But the head of state had abrogated the constitution under which he was elected and which officers were sworn to uphold. Third World armed forces have typically justified seizing political power in terms of preserving the constitution and the nation. In the Philippines, however, the military was incapable of governing. Having played a large part in the Magsaysay administration, where it developed its abhorrance of civilian politicians, the AFP was willing to resume a role in government decision-making.

Martial law gave the military the opportunity to get rid of civilian politicians who they believed were self-serving and had little respect for the majority of the people. Junior officers found themselves performing duties for which they were not adequately trained. Reservist officers were considered more capable of performing civilian functions as they had acquired a more liberal education.

To better prepare PMA officers to perform martial law duties, Marcos shortened the cadetship and modified the academy's curriculum in the early 1970s. Courses on democratic principles had still not been introduced to the Academy, but cadets were taught the concept of civilian supremacy over the military. Other significant changes to the curriculum included placing more emphasis on courses in the humanities as opposed to engineering. This, according to some officers, was designed to better equip cadets to work with civilians and in many cases to replace them. In fact, as martial law became entrenched in the Philippines, AFP officers replaced civilians in many government departments, and also in private corporations which Marcos sequestered from his opponents.

Martial law lasted from 1972 to 1981 . These nine years had a profound effect on the society and the AFP. The AFP was no longer the protector of the nation. Instead, like a private army, it served Marcos and his cronies. Officers became deeply involved in politics as they rigged elections and suppressed the opposition. Self-interest led officers to pursue activities which lost them the respect of the people. And in turn the military lost its raison d'être. More concerned with government than military duties, the AFP was incapable of defeating the growing Communist and Muslim insurgencies; by 1985 the Communist Party of the Philippines (CPP) was claiming control over most of the barangays (villages) in the country. The AFP was even incapable of performing the functions of a conventional armed force in conjunction with American forces.

By and large the AFP remained loyal to an authoritarian civilian leader who satisfied its corporate interests and had no intention of restoring democracy. But some officers came to the conclusion that the prolonged period of martial law 
was working against the president. Widespread dissatisfaction among intellectuals and the middle-class finally surfaced after the 1983 assassination of popular opposition leader Benigno Aquino. Concurrently, factionalism developed in the military as the gap between those benefitting from the system and those fighting the insurgency in the war-torn areas of the countryside increased. The result was that soldiers lost interest in fighting the insurgents, who they believed were justified in their claims, though the military resented their ideology.

A consensus therefore developed among the senior military leadership that 'if the country was to survive as a political system', especially with the CPP/New Peoples Army rapidly gaining ground against the regime, Marcos had to be replaced (Lapitan 1989:237). These views were shared by secretary of defense, Juan Ponce Enrile, and AFP vice chief of staff, General Fidel Ramos. Plans to replace Marcos by a military coup were hastily abandoned when he suddenly announced on television that elections were to be held in February 1986. Surprisingly, the opposition was able to unite against Marcos, backing the widow of Benigno Aquino.

The battle to stop Marcos from cheating Aquino of victory and the defection of elements of the AFP, including General Ramos, culminated in what became popularly known as the 'EDSA revolution' of February 1986. Yet this was not the outcome envisaged by the senior military leaders who had conspired to replace Marcos. Defense Secretary Enrile had nurtured a group of reform-minded officers who shared some of his frustrations with the Marcos regime. These officers formed the Reform the Armed Forces Movement (RAM). With Enrile, they planned to seize political power and install an interim military-civilian council. Aquino was considered a likely member of the council. But when the coup was discovered by Marcos, Enrile joined General Ramos at the armed forces headquarters in Manila and they declared their support for Corazon Aquino. People power resulted from this rebellion which saw the military conceding its desires for political office to Aquino.

The accession of Aquino to the presidency, however, did not stop elements in the military from conspiring to seize political power. Enrile's actions while in the Aquino government, and his subsequent links to a number of the coup attempts, clearly demonstrated his - and the RAM faction's - desire to have a continuing role in government. RAM believed that its claims to a place in government decision-making were justified because it was responsible for assisting Aquino to achieve office (Selochan 1989:8). Enrile also believed that his role in the rebellion against Marcos justified his having a greater role in decision-making. Vice-President Salvador Laurel shared a similar belief, having conceded his presidential ambitions in the interest of Aquino in 1985. Having united in 
their opposition to Marcos, divisions now appeared in the groups that were contending for power - a pattern common in countries that have experienced transition from authoritarian to democratic systems (Huntington 1991).

\section{Reconstituting Democracy}

Much was expected of the Aquino administration. It was anticipated that the government would revive the institutions of democracy abrogated by Marcos in 1972; however, Filipinos also expected the government to take steps to eradicate economic and social inequities. The government promised to reinstate democracy 'but there were no specific social and economic programs that were identified to accomplish the goal of democratisation' (Lapitan 1989:238).

Aquino assumed office with a provisional government under a provisional constitution. This meant that both legislative and executive power was vested in the president until a new constitution was enacted. With the promulgation of a new constitution on 11 February 1987, a new era dawned for democracy in the Philippines. The constitution, which has many similarities with the 1935 American-inspired constitution, has a number of important provisions for the armed forces. Most important of all is the stipulation that active duty officers cannot participate in government.

As promised, elections for all government offices were held throughout the islands under the new constitution by mid 1987. But similarities to the pre-Marcos era were clearly evident as many candidates elected to office were 'former elected officials, relatives of powerful political families and/or members of the powerful economic elite' (Hawes 1989:72). Nevertheless, the elections were competitive and all citizens had the franchise.

Educating the military (which had voted overwhelmingly to reject the constitution) to democratic principles, became one of the issues to be addressed by the 'new' AFP chief of staff, General Ramos. A Training Command was established on 10 December 1986 to coordinate a range of programs to reform the armed forces (Selochan 1990:193). The principal objective of these programs was to restore the tarnished image of the AFP, improve morale and, under a valueformation course, teach the military to respect human rights. Little interest was taken in teaching the military about the need to adhere to democracy.

This did not change even when Marcos supporters and disaffected military elements joined with RAM on July 1986 to stage the first attempted coup against Aquino. It was not until three attempts had been made to seize power, largely by RAM and its supporters, between July 1986 and August 1987, and after PMA cadets had shown a willingness to join in the putsch, that any attempt was made 
to conduct courses for the AFP on the military's role in a democracy (Selochan 1991a:109). Soon after the first coup attempt notices began appearing at all military establishments and courses were taught at the PMA on democracy. Debates about the military's role in a democracy were conducted in the media as retired officers became columnists, arguing for and against the necessity for the AFP to uphold democracy under Aquino. Politicians were invited to talk to soldiers, and seminars on democracy were conducted for AFP personnel. Suddenly, democracy was an issue in the AFP.

Rhetoric, however, differed from reality as elements in the armed forces, backed by politicians and business groups which had profitted under the authoritarian regime and were now unable to acquire the same privileges, were implicated in four further attempts to seize political power. The alliance of politicians and business reflected a common economic interest (Wurfel 1989:681). The factions they supported in the military, however, were incapable of convincing the majority of the AFP that they would benefit from a return to authoritarian rule.

When her term in office ended on 30 June 1992, Aquino proudly claimed that she had achieved her objective of restoring democracy to the Philippines. Elections were scheduled for 11 May 1992. With seven candidates running for the presidency, there were expectations that the military might again attempt to seize power. In fact, however, the elections were peaceful and former AFP chief of staff, General Ramos, was elected to the presidency. Aquino had been confident that democracy was now firmly in place. In her valedictory state of the nation address in June 1992 she said: 'This is the glory of democracy ... that its most solemn moment should be the peaceful transfer of power'.

\section{Conclusion}

Elected president in May 1992 by a quarter of the voters, General Ramos is again faced with protecting a fragile democracy. Given his limited mandate, threats from the RAM and the Communist movement, and a host of economic and social problems, Ramos is likely to ensure that democratic principles are upheld in his administration. Otherwise, challenges will quickly eventuate from those who appear still to prefer authoritarian rule. More unified than in recent years, the AFP leadership appears ready to accept democracy as the only system that will contribute to the economic and social development of the Philippines. For them, it is time that the Philippines shared in the economic dynamism of the Asia-Pacific region and that the military be seen not as a supporter of authoritarianism but as a supporter of democracy in a country that was once put forward as Asia's showcase of democracy. 